This is an open access article under the terms of the CC-BY 3.0 License.

Peer review method: Double-Blind

Date of acceptance: May 25, 2020

Date of publication: August 14, 2020

Original scientific article

DOI https://doi.org/10.47305/JLIA2020045t

UDC 321.64(470+571)

$321.64(479.24)$

\title{
SUSTAINING POWER THROUGH EXTERNAL THREATS: THE POWER OF ENEMY IMAGES IN RUSSIA AND AZERBAIJAN
}

\author{
Aram Terzyan \\ Eurasia Institutes, Los Angeles, USA \\ ORCID iD: https://orcid.org/0000-0002-8439-3678 \\ aramterzyan@gmail.com
}

\begin{abstract}
Despite the growing body of research on authoritarian regimes, few studies address the issues of their legitimization through exaggerating external threats and constructing enemy images. Targeting the gap in the literature, this article explores the discursive strategies of 'evilization' and demonization of the 'other', with a focus on their implications for legitimating and sustaining the authoritarian regimes in post-Soviet space. Examining the cases of Russia and Azerbaijan, the qualitative, comparative analysis presented in this article uncovers a series of essential similarities between the regimes' legitimization strategies. Findings suggest that there has been a strong tendency in both Russian and Azerbaijani discourses to 'externalize' major problems facing the countries and scapegoat 'evil forces' as their main causes. Frequent appeals to the external threats have been accompanied by a heightened emphasis on the necessity of strong presidential power, with 'strongmen' that are capable of withstanding the enemies' conspiracies. Remarkably, one of the core similarities between the two regimes is their unstoppable drive towards monarchical presidencies.
\end{abstract}

Keywords: Russia; Azerbaijan; Authoritarian Regimes; Enemy Images; Legitimation

\section{INTRODUCTION}

Even though the survival strategies of the authoritarian and hybrid regimes in postSoviet countries have been extensively studied, there has been little attention to the legitimation of rulers through the construction of the enemy images and external threats. This study represents an attempt to fill the void, by examining the cases of Russia and Azerbaijan 
during Vladimir Putin's (2012-present) and Ilham Aliyev's (2003-present) presidencies, respectively. The two cases were selected to ensure variance along relevant dimensions of analysis, in order to examine the differences between post-Soviet authoritarian regimes when it comes to legitimation strategies through the enemy images and external threats. We have selected two post-communist countries, the transition of which has been marred by a series of authoritarian malpractices, ranging from centralization and personalization of power to extensive crackdown on civil liberties and political freedoms (Freedom House2019a). One of the core similarities between the two regimes is their unstoppable drive towards monarchical presidencies with hyper-presidents - endowed with unlimited power.

The Arab Awakening, which deposed some of the world's longest-standing autocratic rulers, showed that the autocrats are becoming increasingly vulnerable to youth-driven, social media-powered societies. Thus, both Russian and Azerbaijani 'strongmen' are tasked with sustaining their regime stability, not least through the construction of external threats.

The article contributes to the bulk of literature on the legitimation strategies of the authoritarian regimes. It analyzes the representation of the enemy images in Russian and Azerbaijani presidents' discourses, with a focus on their functions in terms of legitimating and sustaining the authoritarian rule in the two countries. Based on these observations, this article seeks to address the question: how have dissimilar authoritarian regimes sought to engender domestic legitimacy through the construction of external threats and enemy images?

The study relies on critical discourse analysis to explore the core narratives that the Russian and Azerbaijani presidents have employed in the representation of the 'Other'. The study relies on observations from political speeches, newspaper articles, official documents and interviews which provide a body of discourse.

\section{UNDERSTANDING LEGITIMATION AND ENEMY IMAGES IN AUTHORITARIAN REGIMES}

Legitimacy is frequently associated with regime survival, given that it functions as an alternative resource of support for incumbents in turbulent times (Mazepus et al. 2016, 352). Lipset (1959) defines legitimacy as the "the capacity of a political system to engender and maintain the belief that existing political institutions are the most appropriate and proper ones for the society" (p. 86). Authoritarian legitimacy has attracted a lot of academic attention and is largely viewed as something critical that non-democratic rulers seek to acquire or develop through their legitimation claims, symbols, and narratives (Dukalskis and Gerschewski 2017, 253). Huntington (1991) notes that Western democratic systems are less dependent on performance legitimacy than authoritarian systems, as failure is blamed on the incumbents instead of the system, and the ouster and replacement of the incumbents help to renew the system (p. 27). Moreover, the rulers in authoritarian regimes tend to rely heavily on external sources of legitimation, not least through appealing to enemy images and "accusing outside forces of causing every problem that arises on the domestic front" (Shakrai 2015, 33). 
Middens note that "the threat of enemies justifies actions that might otherwise be unacceptable or illegal (...) Enemies serve as a focus for aggression and as a means of diverting attention from pressing internal problems" (Middens 1990). One of the most frequently observed functions of the enemy images is the potential to mobilize for or against an idea or a specific group. Indeed, the mobilizing power of the enemies and external threats would potentially have legitimizing and justifying effects on a government's even most disputed and unpopular policies. The "rhetoric of insecurity" suggested by Cambell seems to accurately capture the basic functions of the enemy images. According to this rhetoric, the state policies are legitimized through the attempt to instill notions of insecurity (Campbell 1998).

To trigger the emotions of fear, the enemy must be portrayed as aggressive, dangerous, threatening, immoral and unreliable. In effect, enemy images and related stereotypes are often characterized by the claim that the enemy has aggressive and evil intentions and is led by a centralized and monolithic leadership that would be capable of carrying out intricate conspiracies (Hermann 2003, 289). The 'evilization' is inherently linked to one of the most frequently observed functions of the enemy images - mobilization of population against the 'Other' (Shakrai 2015, 34). This has much to do with the rally-aroundthe-flag effect that can generate long-lasting public support - conducive to sustaining authoritarian regimes.

To give an idea of the rally-around-the-flag effect, it is noteworthy that the escalation of conflict in Ukraine and the annexation of Crimea have been positively correlated with Putin's growing popularity despite the crippling Western sanctions. This is where the legitimizing effects of the enemy image come into play, with Putin's appeals to external threats helping boost his popularity amid severe economic downturns. A question arises as to what discursive strategies the Russian and Azerbaijani authoritarian rulers use to 'evilize' the enemies and laud the great job that they do standing up to it.

\section{THE REPRESENTATION OF THE 'OTHER' IN RUSSIAN POLITICAL DISCOURSE}

There is a broad consensus among the students of Russian politics about the essential features of the Russian regime-centered around 'putinism'. The latter is viewed as a form autocratic rule that is personalistic, conservative and populist (Fish 2017, 61). The fact that Russian president Vladimir Putin's recent efforts at tailoring the Russian Constitution to his reelection have not run into public resistance, suggests that 'putinism' remains significantly popular with Russians. A question arises as to what specific factors are maintaining Putin's popularity amid excessive crackdown on civil liberties and political freedoms across Russia (Freedom House, 2019a).

It has not been uncommon for Putin to legitimate his regime through exaggerating external threats, emanating particularly from the West. Moreover, the escalation of the crisis in Ukraine has been positively correlated with the 'othering' of the West in Kremlin's

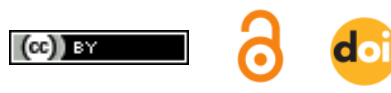


discourse. Some of the characteristics attributed to Western governments by Putin include hypocrisy, Russophobia, lack of moral integrity, recklessness, etc. (Szostek and Hutchings 2015, 185). Clearly, the relationship between Moscow and Washington has reached its nadir since the end of the Cold War, and by December 2014 the concept of an 'iron curtain', separating East and West was again put forward, at least in some analyst circles. Igor Ivanov, Putin's first foreign minister, even suggested that the crisis in Ukraine is more dangerous than the Cold War, as there still is no mutually acceptable mechanism to prevent military clashes (Black and Johns 2016, 227). Furthermore, Putin would regard the 'coup d'état' in Ukraine as a manifestation of a deeper issue of the resurgence of 'nazism' and 'fascism' in Europe: "those who stood behind the latest events in Ukraine resorted to terror, murder and riots. Nationalists, neo-Nazis, Russophobes and anti-Semites executed this coup. They continue to set the tone in Ukraine to this day" (Kremlin 2014). The references to the revival of fascism would be followed by the claim that as a pivotal actor in defeating fascism through World War II, Russia had a crucial mission of preventing its resurgence in Europe.

Interestingly, some Russian analysts tend to claim that Cold War thinking never went away from Western perceptions of international relations, and even see that as part of the crisis outbreak in Ukraine (Black and Johns 2016). Consistent with such contentions, Putin has tended to accuse the USA of the devastation unleashed on Ukraine. In Putin's words, Washington's goal is to 'remake the whole world' around its own interests and thus to impose a 'unilateral diktat' on the rest of the world. Therefore, the crisis in Ukraine was framed an unsurprising consequence of the United States and NATO's hostile and antiRussian policies. They "continue their policy of expanding NATO. What for?" (Washington post 2015).

While blaming the devastating crisis on the United States the Kremlin has tended to contend that fomenting instability in Ukraine is a part of policy that aims to drive a wedge between the two brotherly nations. Moreover, Putin has repeatedly stated that "Russians and Ukrainians are one people" (Trenin 2018). Thus, the Kremlin's discourse suggests that had not the United States of America and European Union made every effort to undermine the Russian-Ukrainian relations, there would have been no considerable frictions between the two brotherly nations. Putin has invariably accused the United States and European Union of their inherently anti-Russian policies, manifested particularly in their double standards on Crimea's 'self-determination'. "We keep hearing from the United States and Western Europe that Kosovo is some special case. What makes it so special in the eyes of our colleagues? (...) This is not even double standards; this is amazing, primitive, blunt cynicism" (Kremlin 2014). Along with activating the Cold War narratives and stereotypes associated with the United States and its policy towards Russia, it has not been uncommon for Putin to treat Washington as 'intellectually inferior' and 'reckless' that suffers from 'imperial adventurism' and lacks strategic foresight. This specifically applies to 'reckless' sanctions imposed on Russia that among others, undermined trust in the dollar as the world's universal currency. "It's a typical mistake of an empire" said Putin and concluded that with its countless strategic mistakes; the

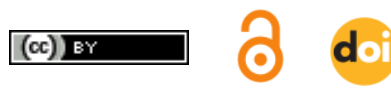


USA is accelerating the end of its global dominance (Abc news 2018). Essentially, by pointing to the acute threats emanating from the USA, he would strive to trigger rally-around-the-flag effect across the Russian population and focus their attention on the necessity of defeating the 'dangerous' but 'reckless' rival.

Moreover, the pronounced emphasis on standing up to the West has served as a convenient pretext to suppress dissent and pluralism across the two country by labeling civic and opposition activists as "anti-Russian spies," or "foreign agents," "traitors," who are involved in the "Western conspiracies" (Yablokov 2018).

Beyond all these, Putin has tended to undermine the very idea of political opposition, by implicitly representing it as an anti-state force backed by anti-Russian forces. Namely, in response to a question about opposition leader Alexei Navalny, Putin stated that Russians "do not want second edition of today's Ukraine for Russia" (France24 2017). As noted earlier, the Russian President would frame the Maidan Revolution as a sign of 'fascism revival'. Such examples would help point to the hypothetical future of a strong opposition that would soon or late become a 'foreign agent' and cause instability. It turns out that considerable part of Russian population tends to share Putin's stances on opposition. Remarkably, a LevadaCentre survey on the necessity of political opposition shows that around 54 percent of respondents thought Russia needed one, while a quarter found it obsolete (Levada 2016). The reasons given by the second group come down to fears about internal divisions and instability that a strong opposition can cause (Levada 2016).

The escalation of conflict in Ukraine and the annexation of Crimea produced rallyaround-the-flag effect, since Putin's approval rating increased to over 85 despite Western crippling economic sanctions (Terzyan 2020). Frequent appeals to the external threats have been accompanied by a heightened emphasis on the necessity of strong presidential power, with a 'strongman', who can withstand the enemy's conspiracies. This discourse has reached a point, where Putin's stay in office is perceived as essential for defending national borderlines. Not surprisingly, in March Russia's Constitutional Court approved amendments that could enable Putin to stay in power for another 16 years.

\section{THE IMAGE OF THE ENEMY IN AZERBAIJANI DISCOURSE}

As a typical authoritarian state, Azerbaijan's political system is characterized by centralization of power and personalistic leadership, as well as weak opposition and massive crackdown on civil liberties and political freedoms (Freedom House, 2019b). Meanwhile, the existence of the external enemy helps President Ilham Aliyev further consolidate his power and justify his undemocratic practices. The long-standing Nagorno Karabakh conflict has been pivotal in targeting Armenia as Azerbaijan's clearly identifiable enemy in Azerbaijani political thinking and public consciousness. One of the most salient features of Azerbaijani President's discourse on Armenia, is the latter's demonization and 'evilization'. Some of the adjectives that Aliyev has used in describing the enemy image of Armenia are "barbarian," 
"vandal," "aggressor," and even a "fascist state": "Armenia is a fascist state. Their national ideology is fascism, discrimination and nationalism" (Azatutyun2014). An integral part of Armenia's 'evilization' has been its representation as bellicose, belligerent and destructive, which is liable for 'freezing' Nagorno Karabakh conflict resolution and causing instability. The "main threat to regional security is posed by the aggressive policy of Armenia against Azerbaijan" (Aliyev 2014).

Nevertheless, the enemy has been framed as 'weak' and 'inferior', that was able to 'occupy' "Azerbaijani lands as a result of foreign intervention" (Elibegova et al. 2018, 7). Moreover, the assertion that Armenia is supported by Russia tends to get invoked as a justification for not wiping "weak," "immoral," "fascist," enemy off the face of the earth (Elibegova et al. 2018). In order to mobilize the Azerbaijani society against the 'evil' enemy and thus legitimate his power, the Azerbaijani President has portrayed Armenia as a 'fake state' built on historical Azerbaijani lands. Such claims have called for unity and patriotism in order to overpower the 'occupant' enemy and restore 'historical justice': "Azerbaijanis will return to Nagorno Karabakh, to other occupied lands and to all the historical Azerbaijani lands" (Massispost 2014).

Consistent with authoritarian rulers' rhetoric, Aliyev has placed a heightened emphasis on military power, thus preparing ground for large-scale militarization. Aliyev's discourse suggests that Azerbaijan's military superiority will be critical to overpowering Armenia. "We will continue to build up our military capabilities. The weaponry and ammunition we have acquired in recent years suggest that we can accomplish any task" (Azernews 2014). Such a rhetoric is typical of personalistic regimes, in which the rules strive to build a 'strongman' image through exaggerating external threats and simultaneously emphasizing their personal characteristics that make them more likely to use military force against the dangerous enemy (Weeks 2012, 326). It is noteworthy, that conspiracy narratives have been strongly associated with the representation of the enemy image of Armenia. The Azerbaijani leadership has strived to create an image of an anti-Azerbaijani, evil and aggressive Armenian lobby, which allegedly conspires to damage or undermine the Azerbaijani statehood: "Our political weight and economic power are growing. (...) Still, there are ill-wishing forces who do not love us. They can be divided into several groups. First, our main enemies are the Armenians from all over the world and the hypocritical, corrupt and bribe-taker politicians who are under their influence" (President.az 2012). Furthermore, the 'externalization' of domestic problems and exaggeration of the enemy image in Aliyev's discourse reached a point, where he accused the Armenian lobby, the scope of whose influence he said 'is quite broad' of the continuing international criticism of Azerbaijan's abysmal human rights record: "An information war is waged against us (...) The Armenian lobby is especially active in that information war. Attempts to badmouth Azerbaijan, to deny Azerbaijan's realities, to present Azerbaijan to the outside world as a backward and undemocratic country primarily result from dirty deeds of the Armenian lobby" (Asbarez 2012). 
It follows that the Armenian lobby is the reason why international watchdog groups, including Amnesty International and Human Rights Watch condemn severe human right violations in Azerbaijan. Clearly, the target audience of such statements is the Azerbaijani population, while the core message is that even if the enemy is 'weak' and 'inferior', the Armenian lobby still poses acute threats to Azerbaijan.

Even the 2018 'Velvet Revolution' that would be largely framed as a major democratic milestone in Armenia, left the Azerbaijani leadership's hard line stances on the enemy intact. Overall, the 'evilization' and demonization of the enemy is consistent with an authoritarian regime's efforts at mobilizing society and sustaining their power through external threats and the enemy image. The latter, as noted earlier, helps divert attention from domestic socioeconomic and political problems and scapegoat the enemy for all troubles.

Furthermore, the necessity of standing up to the external enemy serves as a convenient pretext to suppress dissent and pluralism across the country by labeling opposition activists as 'spies', 'traitors' who are involved in the enemy's conspiracies (Terzyan 2016, 71-72). Frequent appeals to the external threats have been accompanied by a strong emphasis on the necessity of strong, presidential power, with a 'strongman', capable of withstanding enemy's 'conspiracies'.

Unsurprisingly, the referendum held in Azerbaijan in 2009 resulted in abolishing of presidential term limits. Freedom House reports point to widespread suppression of pluralism and a strong tendency of curbing the freedom of speech and controlling the media narrative on politically sensitive issues across the country (Freedom House 2019b). Namely, the legal amendments passed in 2017 tightened government's grip on online media, allowing blocking of websites without a court order if deemed to contain content posing a danger to the state or society (Freedom House 2019b).

Overall, Azerbaijan has been evolving into a 'petro-state' (countries immensely reliant on oil revenues), which often maintain domestic stability by using petrodollars to fund social programs and a strong state security apparatus (Demkiv 2012). Some observers note that petroleum has already made the incumbent authorities rich and powerful enough to address any challenge to their hold on power (Guliyev 2009). Studies show that oil and gas account for about $75 \%$ of state revenue and around 35\% of the gross domestic product (GDP) (Reuters 2019). Oil revenues have become a crucial factor in sustaining Aliyev's regime-based on a system that distributes rents from oil exports through a patronage network in order to ensure unwavering support of allies and major clientelist groups (Guliyev 2009).

Nevertheless, oil-addicted Azerbaijan is highly vulnerable to the fluctuations of international oil prices and tends to find itself in complete economic disarray as the oil prices drop. Unsurprisingly, the Azerbaijani economy got damaged severely in the face of tumbling oil prices in 2016, when prices fell below $\$ 30$ a barrel. This sparked huge economic discontent with rising food prices and deteriorating economic conditions in Azerbaijan as a result of oil price spikes. Along with violently crushing the protests, the Azerbaijani authorities would pull out the 'enemy card' to distract attention from pressing internal problems (BBC 2016). 
The situation came to a head in April, 2016, resulting in the outbreak of heavy fighting between Azerbaijani and Armenian and Armenian armed forces, now known as the 'April War' or 'Four-Day War', in which at least 200 died (Jardine 2018). The 'April war' was well predicted by a well-informed observer, suggesting that the persisting turmoil might well prompt the authorities to 'play the Karabakh card' by starting either large or small operation as a recipe for downplaying the economic hardships and rallying Azerbaijanis around the flag (De Waal 2016). This is where the appeals to external threats and enemy images come into play to produce rally-around-the-flag effects, thus shielding the authorities from mounting public outrage caused by economic downturns.

\section{CONCLUSION}

This article contributes to existing literature on the representation and functions of enemy images in authoritarian regimes by examining the cases of Russia and Azerbaijan. Based on the previous discussion, there are several concluding observations to make regarding the 'othering' and regime legitimation strategies in Russian and Azerbaijani political discourses.

Both in Russian and Azerbaijani discourses there have been a propensity to accuse the enemies of causing major problems facing the countries. The escalation of the crisis in Ukraine has been positively correlated with the 'othering' of the West in Kremlin's discourse. Putin's discourse has been characterized by a strong tendency to blame the outbreak of the Russian-Ukrainian conflict on the West and primarily on the United States - repeatedly accused of anti-Russian policies, aimed to 'remake the whole world' around its own interests.

Similarly, Azerbaijan's clearly identifiable enemy Armenia has been framed as destructive, belligerent and bellicose, that causes instability and devastation, by 'freezing' the Nagorno Karabakh conflict resolution.

The 'Others' have been 'evilized' and demonized in both Russian and Azerbaijani discourses. Some of the characteristics attributed to Western governments by Putin include hypocrisy, Russophobia, lack of moral integrity and recklessness. Moreover, the Kremlin has framed the Ukrainian crisis as a struggle against 'fascism', as those who staged the Maidan Revolution were labeled as nationalists, neo-Nazis, Russophobes and anti-Semites.

The references to the 'revival of fascism' would be followed by the claim, that Russia had a crucial mission of preventing its resurgence in Europe.

As for the 'evilization' of Azerbaijan's enemy, it is noteworthy that some of the adjectives that Aliyev has used in describing the enemy image of Armenia are 'barbarian', 'vandal', 'occupant' and 'aggressor', and even a 'fascist state'. The 'evilization' and demonization of the enemy has rhetorically necessitated the use military force against 'the evil'. In order to mobilize the Azerbaijani society against the 'evil' enemy and legitimate his power, the Azerbaijani President has portrayed Armenia as a 'fake state' built on historical Azerbaijani lands.

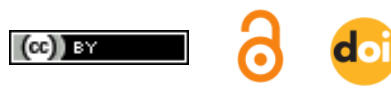


Such claims have called for unity and patriotism in order to overpower the 'occupant' enemy and restore 'historical justice'. Both Russian and Azerbaijani leaderships have consistently strived to trigger rally-around-the-flag effect through the construction of the external threats and the enemy images. Remarkably, the escalation of conflict in Ukraine and the annexation of Crimea have been positively correlated with Putin's growing popularity despite the crippling Western sanctions.

As a typical petro-state Azerbaijan is highly vulnerable to the fluctuations of international oil prices and tends to find itself in complete economic disarray as the oil prices drop. This is where the appeals to external threats and enemy images come into play thus shielding the authorities from public outrage caused by economic downturn.

The necessity of standing up to the enemy has served as a convenient pretext to suppress dissent and pluralism across the two countries by labeling opposition activists as 'spies', 'foreign agents', 'traitors' who are involved in the enemies' conspiracies. Such rhetoric is not uncommon in authoritarian regimes, where leaders tend to strengthen their popularity by exaggerating external threats and exploiting nationalism.

Frequent appeals to the external threats have been accompanied by a heightened emphasis on the necessity of strong presidential power, with 'strongmen', who are capable of withstanding the enemies' conspiracies. Not surprisingly, one of the core similarities between the two regimes is their unstoppable drive towards monarchical presidencies. Further research is essential to account for Russian and Azerbaijani incumbents' evolving strategies of sustaining power through external threats and enemy images. 


\section{REFERENCES}

1. Abcnews. 2018. "Russian President Vladimir Putin Says US Dominance is Ending After Mistakes 'Typical of an Empire." Accessed April 17, 2020.

https://abcnews.go.com/International/putin-us-dominance-ending-mistakes-typicalempire/story?id $=58611354$

2. Aliyev, Ilham. 2014. Twitter Post. October 1, 2014. Accessed April 17, 2020. https://twitter.com/presidentaz/status/517274762351898625

3. Asbarez. 2012. "Aliyev Blames Armenian Lobby for Azeri Human Rights Abuses." Accessed April 17, 2020. http://asbarez.com/102409/aliyev-blames-armenian-lobbyfor-azeri-human-rights-abuses/

4. Azatutyun. 2014. "Armenia 'Fascist State,' Says Aliyev." Accessed April 17, 2020. https://www.azatutyun.am/a/25304315.html

5. Azernews. 2014. "President Aliyev Says Azerbaijan Ready for Any Scenario." Accessed April 17, 2020. http://www.azernews.az/azerbaijan/69476.html

6. BBC. 2016. "Azerbaijan Hit by Price Protests Amid Oil Slump." Accessed April 17, 2020. https://www.bbc.com/news/world-europe-35316359

7. Black, Joseph Laurence, and Michael Johns, eds. 2016. The Return of the Cold War: Ukraine, the West and Russia. Routledge.

8. De Waal, Thomas. 2016. "Azerbaijan's Perfect Storm." Carnegie Europe. Accessed April 17, 2020. http://carnegieeurope.eu/strategiceurope/?fa=62501

9. Demkiv, Anita. 2012. "Political Instability in Petrostates: The Myth or Reality of Oil Revenue as Petrostate Stabilizer." PhD diss., Rutgers University-Graduate SchoolNewark. Accessed April 17, 2020. https://rucore.libraries.rutgers.edu/rutgers$\underline{\text { lib/37303/ }}$

10. Dukalskis, Alexander, and Johannes Gerschewski. 2017. "What Autocracies Say (and What Citizens Hear): Proposing Four Mechanisms of Autocratic Legitimation." Contemporary Politics 23, no. 3: 251-268.

11. Elibegova, Anzhela, Gevorgyan, Levon. and Kirakosyan, Yeghishe. 2018. "Armenophobia in Azerbaijan: Organized Hate Speech and Animosity Towards Armenians." Accessed April 17, 2020. https://ombudsmannkr.codics.solutions/ru/document/570

12. France24. 2017. "As elections near, Putin says Russians will not stand for Ukraine-style coup." Accessed April 28, 2020. https://www.france24.com/en/20171214-putin-pressconference-us-provoked-north-korea

13. Fish, M. Steven. "The Kremlin Emboldened: What Is Putinism?" Journal of Democracy 28, no. 4 (2017): 61-75.

14. Freedom House. 2019a. "Countries and Territories." Accessed April 17, 2020. https://freedomhouse.org/countries/freedom-world/scores 
15. Freedom House. 2019b. "Freedom in the World 2019: Azerbaijan." Accessed April 17, 2020. https://freedomhouse.org/country/azerbaijan/freedom-world/2019

16. Guliyev, Farid. 2009. "End of Term Limits: Monarchical Presidencies on the rise." Harvard International Review. Accessed April 17, 2020. https://papers.ssrn.com/sol3/papers.cfm?abstract id=1417532

17. Guliyev, Farid. 2013. "Oil and Regime Stability in Azerbaijan." Demokratizatsiya 21, no. 1: $113-147$.

18. Huntington, Samuel P. 1991. "Democracy's Third Wave." Journal of democracy 2, no. 2: $12-34$.

19. Jardine, Bradley. 2018. "Armenians and Azerbaijanis Commemorate Two Years Since Breakout of "April War."Accessed April 17, 2020. https://eurasianet.org/armeniansand-azerbaijanis-commemorate-two-years-since-breakout-of-april-war

20. Kremlin. 2014. "Address by the President of Russian Federation." Accessed April 17, 2020. http://en.kremlin.ru/events/president/news/20603

21. Levada. 2016. "Oppozitsiya: Neobkhodimost, Uznavaemost i Doverie" [Opposition: Necessity, recognition and trust]. Levada-Centre. Accessed April 17, 2020. https://www.levada.ru/2016/03/14/oppozitsiya-neobhodimostuznavaemost-i-doverie/

22. Lipset, Seymour Martin. 1959. "Some Social Requisites of Democracy: Economic Development and Political Legitimacy." American political science review 53, no. 1: 69105.

23. Massispost. 2014. "Iham Aliyev Wants Nagorno-Karabakh, to other Occupied Lands and "Hstorical Azerbaijani Lands." Accessed April 17, 2020. https://massispost.com/2014/03/ilham-aliyev-wants-nagorno-karabakh-and-historicalazerbaijani-lands-back/

24. Mazepus, Honorata, WouterVeenendaal, Anthea McCarthy-Jones, and Juan Manuel Trak Vásquez. 2016. "A Comparative Study of Legitimation Strategies in Hybrid Regimes." Policy Studies 37, no. 4: 350-369.

25. Middens, Gerald J. 1990. "Psychological Perspectives on Enemy-Making." Organization Development Journal: 44-48.

26. President.az. 2012. "Ilham Aliyev Attended a Conference on the Results of the Third Year into the "State Program on the Socioeconomic Development of Districts for 2009-2013." Accessed April 17, 2020. https://en.president.az/articles/4400

27. Reuters. 2019. "Azerbaijan's GDP Seen Up 2.4\% in 2020, Oil Price $\$ 55$ per Barrel Budget Draft." Accessed April 17, 2020. https://www.reuters.com/article/azerbaijanbudget/azerbaijans-gdp-seen-up-24-in-2020-oil-price-55-per-barrel-budget-draftidUSL5N2675FW

28. Shakrai, Ina. 2015. "The Legitimization of Authoritarian Rule Through Constructed External Threats: Russian Propaganda During the Ukrainian Crisis." East European Quarterly 43, no. 1: 29-54. 
29. Szostek, Joanna, and S. Hutchings. 2015. "Dominant Narratives in Russian Political and Media Discourse During the Ukraine Crisis." Ukraine and Russia: People, Politics, Propaganda and Perspectives: 183-196.

30. Terzyan, Aram. 2016. "The Role of Beliefs in Armenia-Azerbaijan Confrontation: A Glance into Presidents' Discourse." Armenian Journal of Poltical Science no 1: 65-80

31. Terzyan, Aram. 2020. Towards a Monarchical Presidency in Russia. New Eastern Europe. Accessed April 17, 2020. https://neweasterneurope.eu/2020/04/17/towards-amonarchical-presidency-in-russia

32. Trenin, Dmitri. 2018. "Russia and Ukraine: From Brothers to Neighbors."Carnegie Moscow Center. Accessed April 17, 2020. https://carnegie.ru/commentary/75847

33. Washingtonpost. 2015. "Read Putin's U.N. General Assembly speech." Accessed April 17, 2020. https://www.washingtonpost.com/news/worldviews/wp/2015/09/28/readputins-u-n-general-assembly-speech/

34. Weeks, Jessica L. 2012. "Strongmen and Straw Men: Authoritarian Regimes and the Initiation of International Conflict." American Political Science Review 106, no. 2: 326347.

35. Yablokov, Ilya. 2018. Fortress Russia: Conspiracy theories in the post-Soviet world. John Wiley \& Sons. 